\title{
PERSEPSI TERHADAP PENTINGNYA MATA KULIAH AKUNTANSI FORENSIK DALAM KURIKULUM PRODI AKUNTANSI FAKULTAS EKONOMI DAN BISNIS UNIVERSITAS WIRARAJA
}

\author{
Febri Achmad Faraid ${ }^{1}$, Syahril ${ }^{2}$, Arief Hidayatullah Khamainy ${ }^{3}$ \\ ${ }^{1,2,3)}$ Fakultas Ekonomi dan Bisnis Universitas Wiraraja \\ Email:febryarap@gmail.com
}

\begin{abstract}
ABSTRAK
Penelitian ini bertujuan untuk mengetahui tentang persepsi terhadap pentingnya mata kuliah akuntansi forensik dalam kurikulum Program Studi Akuntansi Fakultas Ekonomi Dan Bisnis Universiras Wiraraja. Dalam penelitian ini menggunakan data kualitatif. Untuk mendeskripsikan, menganalisis dan menarik kesimpulan tentang persepsi dosen, mahasiswa dan stakeholder terhadap pentingnya mata kuliah akuntansi forensik dalam kurikulum prodi Akuntansi Fakultas Ekonomi Dan Bisnis Universitas Wiraraja. Hasil dari penelitian ini menjelaskan bahwa (1) terdapat satu dosen akuntansi yang berpendapat bahwa akuntansi forensik perlu dimasukkan kedalam kurikulum prodi akuntansi. Dan dua lainnya berpendapat tidak perlu. (2) terdapat dua mahasiswa akuntansi yang berpendapat bahwa akuntansi forensik perlu dimasukkan kedalam kurikulum program studi akuntansi dan dua lainnya berpendapat tidak perlu. (3) stakeholder berpendapat bahwa akuntansi forensik perlu dimasukkan kedalam kurikulum program studi akuntansi. Paling tidak mahasiswa memiliki pengetahuan mendasar tentang akuntansi forensik dan dapat digunakan sebagai bekal atau acuan bagi mahasiswa akuntansi.
\end{abstract}

Kata Kunci : Akuntansi Forensik, Kurikulum Program Studi Akuntansi.

\section{INTRODUCTION}

Banyaknya tindak kecurangan yang dilakukan dalam institusi pemerintah maupun non pemerintah memberikan gambaran bahwa tindak kecurangan telah lekat di lingkungan masyarakat. Upaya pemberantasan terhandap kejahatan-kejahatan kleptorat di lingkungan sektor publik sudah mulai banyak dilakukan, namun masih belum menemukan hasil yang maksimal. (Setiawan, dkk., 2013). Kasus yang terbaru yaitu mengenai tindak pidana korupsi yang ada di Indonesia pada tahun 2017, Indonesia Corupption Watch (ICW) mencatat ada 226 kasus korupsi. Kasus dengan jumlah tersangka 587 orang itu merugikan negara $\mathrm{Rp} 1,83$ triliun dan nilai suap Rp 118,1 miliar. (DetikNews). Hal ini menunjukkan bahwa praktik korupsi masih banyak yang belum teratasi. Korupsi tidak bisa dikatakan hal yang biasa saja karena terlalu banyak pihak yang dirugikan. sehingga dibutuhkan upaya dalam hal menangani tindak pidana korupsi. baik dalam perspektif pencegahan, tindakan maupun dalam bidang keilmuan seperti halnya akuntansi forensik.

Mahasiswa saat ini mempunyai peran penting dalam hal pemberantasan fraud yang ada di Indonesia melalui penerapan ilmu yang dimilikinya. Oleh karena itu Mahasiswa akuntansi perlu mempelajari akuntansi forensik lebih mendalam sebagai wujud partisipasi dalam mencegah dan menyelesaikan kasus fraud yang saat ini sudah banyak terjadi di Indonesia. Jurusan akuntansi memiliki tujuan untuk membentuk lulusan yang professional, berkarakter dan 
berkompetensi dalam disiplin ilmu akuntansi. Kurikulum harus bisa disesuaikan dengan lingkungan akademis serta profesi yang dibutuhkan pada saat perkembangan bisnis semakin meningkat. Maka perlu dipertimbangkan kembali oleh tenaga pendidikan akuntansi tentang masalah kurikulum dan arah tujuan pendidikan sarjana akuntansi.

Universitas Wiraraja merupakan Universitas swasta terbesar di kabupaten Sumenep. Sebagai perguruan tinggi terbesar yang ada di daerah Sumenep maka membuat Universitas Wiraraja menjadi favorit bagi mahasiswa baru. Sampai saat ini Universitas Wiraraja mempunyai 7 (tujuh) fakultas dan salah satunya adalah fakultas ekonomi dan bisnis. Fakultas ekonomi sendiri mempunyai 2 (dua) program studi yaitu program studi manajemen dan program studi akuntansi. Program Studi Akuntansi merupakan salah satu program studi yang ada dalam ruang lingkup Fakultas Ekonomi dan Bisnis. Namun sampai saat ini Program Studi Akuntansi FEB Universitas Wiraraja masih belum memasukkan Akuntansi Forensik menjadi salah satu mata kuliah wajib atau pilihan dalam kurikulum Program Studi Akuntansi Fakultas Ekonomi dan Bisnis.

Mengingat beberapa kasus yang telah dipaparkan diatas maka Akuntansi Forensik dapat menjadi bahan pertimbangan bagi pogram studi Akuntansi Fakultas Ekonomi dan Bisnis Universitas Wiraraja untuk menjadi mata kuliah tersendiri supaya Mahasiswa dapat memahami Akuntansi Forensik secara mendalam. Karena sampai saat ini pemahaman tentang Akuntansi Forensik atau Audit Kecurangan hanya disampaikan pada mata kuliah Audit Internal. Perubahan kurikulum bisa menjadi jalan untuk masuknya Akuntansi Forensik menjadi mata kuliah tersendiri di Program Studi Akuntansi Fakultas Ekonomi dan Bisnis Universitas Wiraraja.

\section{LITERATURE REVIEW \\ Persepsi}

Menurut Rakhmat

(2007:51)

menjelaskan bahwa persepsi merupakan suatu pengalaman tentang objek, peristiwa atau hubungan-hubungan yang diperoleh dengan menyimpulkan informasi atau pesan. Dengan demikian persepsi adalah hasil pikiran seseorang dari beberapa situasi tertentu. sedangkan menurut Walgito (2010:99) mendefinisikan persepsi sebagai suatu proses yang didahului oleh proses penginderaan, yaitu suatu proses diterimanya stimulus oleh pikiran manusia melalui panca indera atau juga disebut sebagai proses sensoris. Lalu kemudian stimulus tersebut dilanjutkan menjadi proses persepsi.

\section{Akuntansi Forensik}

Menurut Tuanakotta mendefinisikan akuntansi forensik adalah penerapan disiplin akuntansi dalam arti luas, termasuk auditing pada masalah hukum untuk penyelesaian hukum di luar pengadilan. Sedangkan menurut AICPA (The American Institute of Certified Public Accountant) mendefinisikan akuntansi forensik sebagai penerapan prinsip akuntansi, teori, dan disiplin untuk mengungkap fakta atau hipotesis isu-isu di dalam sengketa hukum dan merupakan cabang akuntansi yang mencakup setiap pengetahuan tentang Akuntansi (Davis dkk., 2010).

\section{METHODS}

Penelitian ini merupakan jenis penelitian kualitatif sebagai metode penelitian untuk mengungkap dan mengetahui tentang 
persepsi pentingnya mata kuliah akuntansi forensik dalam kurikulum prodi akuntansi fakultas ekonomi dan bisnis universitas wiraraja. Informan yang dipilih dalam penelitian ini yaitu dosen sebagai akuntan pendidik dan mahasiswa S1 akuntansi Fakultas Ekonomi dan Bisnis Universitas Wiraraja dengan pertimbangan bahwa mereka memiliki persepsi dibidang akuntansi dan auditing. informan lainnya adalah stakeholder akuntansi yaitu pegawai inspektorat pemerintah Kabupaten Sumenep dan pegawai PT. BPRS sumenep dengan pertimbangan bahwa mereka memiliki persepsi dibidang akuntansi forensik dan auditing.

Dalam melaksanakan wawancara peneliti tidak membatasi pada satu waktu dan tempat saja. wawancara dapat dilakukan dimana saja guna menjaga kenyamanan informan supaya tidak terlihat kaku dan tidak nyaman pada saat wawancara berlangsung. Teknik analisis data yang digunakan dalam penelitian ini yaitu dengan menggunakan analisis reduksi data, penyajian data dan kesimpulan/verifikasi. Kemudian peneliti melakukan uji keabsahan, pada penelitian ini digunakan uji kredibelitas untuk menguji keabsahan data yaitu perpanjangan pengamatan, meningkatkan ketekunan dan triangulasi.

\section{RESULTS AND DISCUSSIONS}

Universitas Wiraraja merupakan universitas swasta terbesar yang ada di Kabupaten Sumenep. Berdiri pada tanggal 25 juni 1986 dan pada tahun 1988 Universitas Wiraraja berhasil memperoleh ijin dari Menteri Pendidikan dan Kebudayaan RI yang dinyatakan dalam SK Nomor : 0618/O/1989. Sampai saat ini Universitas Wiraraja mempunyai 7 fakultas dan 1 pascasarjana.
Salah satunya adalah Fakultas Ekonomi Dan Bisnis.

Program studi (jurusan) akuntansi merupakan salah satu program studi yang terdapat dalam lingkungan fakultas ekonomi dan bisnis Universitas Wiraraja. Program studi akuntansi mempunyai visi untuk menjadikan menjadi program studi akuntansi S1 yang unggul dalam keilmuan akuntansi berbasis riset, berjiiwa entrepreneur serta menjunjung tinggi nilai-nilai etika dan moral yang berorientasi pada peningkatan perekonomian daerah.

Kurikulum Program Studi Akuntansi Fakultas Ekonomi Dan Bisnis Universitas Wiraraja sendiri mengacu pada kurikulum yang berbasis KKNI (Kerangka Kualifikasi Nasional Indonesia) yang merupakan desain kurikulum terbaru di Program Studi Akuntansi yang di update pada tahun 2015 dan kemudian diterapkan pada tahun 2016 oleh Program Studi Akuntansi Fakultas Ekonomi Dan Bisnis Universitas Wiraraja sesuai dengan kebijakan ketua program studi akuntansi. Kurikulum disusun atas dasar tuntutan perubahan kurikulum yang mengharuskan untuk berbasis KKNI kemudian disesuikan dengan kebutuhan tenaga kerja yang saat ini dibutuhkan dipasaran.

Menurut Tuanakotta

mendefinisikan akuntansi forensik adalah penerapan disiplin akuntansi dalam arti luas, termasuk auditing pada masalah hukum untuk penyelesaian hukum di luar pengadilan. Akuntansi forensik merupakan suatu terapan ilmu baru profesi akuntan yang bergerak dalam bidang pelayanan jasa untuk memecahkan persoalan pada suatu kasus kecurangan fraud. Namun sampai saat ini akuntansi forensik masih kurang diminati dan masih jauh dari harapan sehingga mahasiswa 
akuntansi belum tentu mengerti sepenuhnya tentang akuntansi forensik. dalam penelitian ini, peneliti lebih memfokuskan pada persepsi dosen, mahasiswa, stakeholder terhadap pentingnya mata kuliah akuntansi forensik dalam kurikulum prodi akuntansi fakultas ekonomi dan bisnis universitas wiraraja.

\section{Persepsi Dosen Akuntansi Terhadap Pentingnya Mata Kuliah Akuntansi Forensik dalam Kurikulum Jurusan Akuntansi Fakultas Ekonomi dan Bisnis Universitas Wiraraja.}

Dosen merupakan suatu individu atau orang yang menjadi tenaga pengajar pada perguruan tinggi. Dosen pada perguruan tinggi yang mendidik mahasiswa akuntansi harus memiliki komitmen untuk mengembangkan kualits-kualitas yang layak agar dapat memenuhi kebutuhan dunia kerja pada saat ini. peneliti mewawancarai dosen audit internal sesusai mengajar mengungkapkan :

"Untuk saat ini khususnya mahasiswa akuntansi perlu dibekali terkait dengan akuntansi forensik, karena harapan kedepannya profesi mereka di bidang akuntansi misalnya pada staff keuangan atau sebagai auditor. Apalagi jika menjadi seorang auditor itu harus tau tentang akuntansi forensik mengingat didalam auditor itu mengungkap adanya ketidak wajaran dalam laporan keuangan dan itu nanti berkolerasi dengan adanya tindak kecurangan misalnya korupsi, penggelapan yang nantinya butuh dengan pemikiran-pemikiran orang akuntan itu berpemikiran sebagai akuntan forensik".

Terdapat harapan yang sangat besar terhadap mahasiswa jurusan akuntansi karena mahasiswa akuntansi yang memilih akan fokus didalam disiplin ilmu audit atau staff bagian keuangan harus mengetahui tentang akuntansi forensik. Harapan itu bisa digapai dengan cara memasukkan mata kuliah akuntansi forensik kedalam kurikulum jurusan akuntansi universitas wiraraja yang nantinya akan membuat mahasiswa wiraraja menjadi problem solver di lingkungan masyarakat.

Pendapat ini berbeda dengan dosen akuntansi lainnya yaitu (norsain) yang juga sempat berdiskusi dengan peneliti berkata:

"Untuk S1 itu kayaknya sih belum waktunya untuk memasukkan akuntansi forensik sebagai sebuah mata kuliah dikurikulum S1. Karena standar kurikulumnya belum memberikan dasar. Jadi cukup dimasukkan sebagai salah satu bahan di mata kuliah tertentu di audit internal atau auditing".

Di satu sisi, Bapak Norsain selaku dosen auditing juga lebih lugas mengungkapkan bahwa akuntansi forensik cukup diperkenalkan atau cukup menjadi bagian di mata kuliah lain misalnya seperti audit internal atau auditing. Keahlian dalam bidang akuntansi forensik tidak hanya bisa didapat pada suatu keahlian akademis. Akan tetapi perlu melakukan pelatihan sertifikasi seperti ACFE (Association of Certified Fraud Examiners) yang tidak dapat diperoleh pada bidang akademik. Karena akuntansi forensik bersifat teknis. Sementara kajian-kajian akademis dapat diperoleh pada jenjang S2 akuntansi forensik. Dan untuk saat ini S1 belum bisa mengkonformasi bidang akuntansi forensik sebagai mata kuliah dan cukup diberikan hanya sebatas pada pengenalan saja dan tidak perlu untuk diperdalam.

Hal senada juga di ungkapkan oleh Ketua Program Studi Akuntansi tentang pentingnya akuntansi forensik yaitu Moh. Herli yang mengungkapkan bahwa:

"Kalau melihat penting tidaknya itu melihat kebutuhan pasar. Pasar butuh 
ndak ada mata kuliah akuntansi forensik? Kalau sekiranya butuh ya kita masukkan."

Ketua program studi akuntansi dengan lugas mengungkapkan bahwa terdapat beberapa mata kuliah yang harus direvisi dalam kurikulum program studi akuntansi. Karena suatu kurikulum perguruan tinggi harus seimbang dengan kebutuhan tenaga kerja yang saat ini dibutuhkan.

Persepsi Mahasiswa Akuntansi Terhadap Pentingnya Mata Kuliah Akuntansi Forensik dalam Kurikulum Jurusan Akuntansi Fakultas Ekonomi dan Bisnis Universitas Wiraraja.

Peneliti mewawancarai beberapa mahasiswa akuntansi semester 6 mengenai pentingnya mata kuliah akuntansi forensik. Salah satunya informan Putri yang berpendapat bahwa:

"Kalau menurut saya sih perlu, karena biar banyak nanti lulusan di universitas wiraraja yang bisa bergerak dibidang akuntansi forensik. Dan bisa juga di universitas wiraraja ini dengan adanya mata kuliah akuntansi forensik bisa mendapatkan pekerjaan dengan cepat, karena akuntansi forensik di Indonesia sangat kurang peminatnya. Seperti itu."

Berdasarkan hasil wawancara diatas maka dapat disimpulkan bahwa akuntansi forensik sangat diperlukan karena akuntansi forensik dapat menjadi peluang karir yang baik bagi lulusan akuntansi yang ingin fokus khususnya dibidang akuntansi forensik.

Berbeda dengan pendapat informan Putri, Informan Dendy juga memberikan pendapat bahwa:

"Menurut saya pribadi tidak perlu. Karena ini lebih ke profesi. Soalnya jika kita menerapkan di S1 terlalu berat. Kita harus mengerti dan paham dengan audit dan kita juga harus paham tentang hukum disini. Ini menggabungkan beberapa ilmu menjadi satu. Jadi terlalu berat. Ini lebih ke masalah keahlian dan profesi. Jadi menurut saya, untuk jenjang S1 masih belum perlu."

Hasil wawancara dengan informan dendy menunjukkan bahwa akuntansi forensik masih belum perlu dimasukkan kedalam kurikulum program studi akuntansi. Karena akuntansi forensik merupakan suatu bidang profesi yang harus bersertifikasi dan dibutuhkan keahlian yang handal untuk dapat ahli dibidang akuntansi forensik. Maka untuk jenjang strata-1 akuntansi masih belum perlu dimasukkan kedalam kurikulum.

Peneliti mewawancarai informan Yesi dengan memberikan pendapat bahwa:

"Kalau menurut saya saat ini itu masih kurang, maksudnya jangan dulu dimasukkan kedalam kurikulum jurusan akuntansi. Karena untuk dunia kerja di sumenep sendiri masih sedikit KAP. Jadi, feedbacknya nanti kalau sudah memahami tentang akuntansi forensik ujung-ujungnya muaranya kita bekerja sebagai audit forensik. Sedangkan dunia kerja disumenep masih jarang tentag hal tersebut".

Ungkapan dari mahasiswa diatas lebih menekankan pada kebutuhan akan profesi akuntan forensik di daerah sumenep sehingga berpendapat bahwa akuntansi forensik masih belum perlu dimasukkan kedalam kurikulum jurusan akuntansi. Karena pada umumnya profesi akuntansi forensik masih jarang digunakan khususnya pada daerah kabupaten sumenep. Hal ini terlihat karena di daerah sumenep sendiri masih belum ada Kantor Akuntan Publik (KAP) yang menaungi auditor dan termasuk akuntan forensik didalamnya.

Berbeda halnya dengan pendapat Akhmad Sutrisno terkait dengan pentingnya 
mata kuliah akuntansi forensik dalam kurikulum jurusan akuntansi. Yang mengungkapkan:

"Kalau masalah dimasukkan kedalam kurikulum atau tidaknya kurang begitu paham, tapi saya rasa perlu. Karena mata kuliah akuntansi forensik itu sangat dibutuhkan. Hanya saja kalau cuma dipelajari dalam satu mata kuliah saya rasa kurang terlalu dalam. Mungkin kalau mau benar-benar paham di akuntansi forensik harus mengambil dipenjurusan yang berfokus di akuntansi forensik".

Menurut informan Akhmad Sutrisno Akuntansi forensik perlu di masukkan kedalam kurikulum jurusan akuntansi. Karena mahasiswa akuntansi perlu dibekali dengan ilmu yang dapat mendeteksi, mencegah dan menyelesaikan kecurangan. Akan tetapi akuntansi forensik merupakan suatu disiplin ilmu yang terbilang cukup sulit karena akuntansi forensik merupakan terapan berbagai macam ilmu didalamnya. Akuntansi forensik sendiri merupakan suatu ilmu akuntansi yang bersertefikasi. Maka pemberian mata kuliah akuntansi forensik dalam strata-1 akuntansi bisa menjadi bekal bagi mahasiswa untuk berfokus dibidang akuntansi forensik.

Persepsi Stakeholder Terhadap Pentingnya Mata Kuliah Akuntansi Forensik dalam Kurikulum Program Studi Akuntansi Fakultas Ekonomi dan Bisnis Universitas Wiraraja.

Stakeholder sebagai pihak pengguna lulusan akuntansi merupakan konsumen bagi output sebuah perguruan tinggi. Stakeholder sendiri bisa berupa institusi pemerintah, swasta maupun perorangan. Peneliti mewawancarai pegawai Inspektorat Pemerintah Kabupaten Sumenep yaitu Moh. Fatah Firdaus yang memberikan tanggapan cukup serius terkait fokus dalam penelitian ini mengungkapkan:

"Seharusnya sih perlu, Cuma masalahnya gini, untuk forensik sendiri ini butuh pendalaman lagi, istilahnya kalau hanya sekali duakali dapat mata kuliah akuntansi forensik sepertinya belum terlalu mempuni dalam melakukan audit forensik. Jadi tetap ada semacam pengantar satu dua semester. Untuk akuntansi forensik. Nah untuk pengembangannya sendiri ada sertifikasinya tersendiri”.

Hasil percakapan dari sebuah wawancara yang dilakukan di kantor isnpektorat ini menunjukkan bahwa akuntansi forensik perlu dimasukkan kedalam kurikulum jurusan akuntansi. Namun mengingat akuntansi forensik merupakan sebuah bidang ilmu yang terbilang sulit maka akuntansi forensik tidak hanya bisa diberikan pada satu mata kuliah saja. Perlu beberapa mata kuliah dan pelatihan atau praktik akuntansi forensik supaya mahasiswa benar-benar bisa mendalami akuntansi forensik itu sendiri.

Peneliti juga melakukan wawancara dengan stakeholder yaitu salah satu karyawan bank BPRS ibu Endang terkait dengan pentingnya mata kuliah akuntansi forensik dimasukkan kedalam kurikulum jurusan akuntansi:

"Perlu, itu kan sebagai antisipasi terjadinya tindak kecurangan. Paling tidak mahasiswa itu tau. Seperti dalam bidang ekonomi, akuntansi itu hanya ada satu kali. Nanti ka nada penjurusan atau sertifikasi nah dari situ kita bisa mengambil acuan untuk mengambil fokus dalam bidang akuntansi forensik."

Melihat ungkapan dari stakeholder diatas, peneliti menyimpulkan bahwa akuntansi forensik perlu menjadi sebuah mata kuliah. Stakeholder lebih menekankan pada 
pemilihan karir mahasiswa akuntansi yang nanti akan berfokus pada bidang akuntansi forensik. Sehingga dapat memiliki acuan dalam memilih keputusan untuk mengikuti sertifikasi akuntansi forensik ataupun yang ingin melanjutkan pada jenjang S2 yang berfokus pada bidang akuntansi forensik.

Hasil penelitian tentang persepsi dosen terhadap pentingnya mata kuliah akuntansi forensik dalam kurikulum Program Studi Akuntansi Fakultas Ekonomi Dan Bisnis Universitas Wiraraja terjadi adanya kontradiksi atau perbedaan pendapat antara beberapa dosen akuntansi. Dimana dosen audit internal (Moh. Faisol) berpendapat bahwa akuntansi forensik perlu dimasukkan kedalam kurikulum dan dijadikan sebagai mata kuliah tersendiri karena sampai saat ini akuntansi forensik mulai dibutuhkan terkait dengan banyaknya kecurangan yang terjadi. Maka dari itu mahasiswa perlu dibekali dengan akuntansi forensik, paling tidak mahasiswa mempunyai pemahaman mendasar tentang akuntansi forensik itu sendiri.

Sementara itu dosen auditing (Norsain) lebih menekankan pada keahlian dalam bidang akuntansi forensik yang tidak hanya bisa didapatkan pada jenjang pendidikan S1, perlu adanya suatu pelatihan khusus atau sertifikasi seperti ACFE (Association Of Certified Fraud Examiners) untuk ahli dalam bidang akuntansi forensik. Oleh karena itu akuntansi forensik tidak perlu dimasukkan kedalam kurikulum jurusan akuntansi. Cukup diperkenalkan pada mahasiswa atau menjadi bagian dari salah satu mata kuliah seperti audit internal.

Kebutuhan akan profesi akuntansi forensik yang masih tidak terlalu dibutuhkan khususnya di daerah Sumenep menjadi alasan bagi Moh. Herli selaku ketua program studi akuntansi sampai saat ini belum memasukkan mata kuliah akuntansi forensik kedalam kurikulum jurusan akuntansi. Karena akuntansi forensik dianggap masih belum menjadi syarat yang harus dimasukkan kedalam kurikulum yang berbasis KKNI. untuk itu perlu dilakukan beberapa pertimbangan seperti halnya kebutuhan dunia kerja terkait dengan lulusan akuntansi yang dibekali dengan akuntansi forensik khususnya di daerah sumenep.

Sementara itu, penekanan atas kualitas akademis di program studi akuntansi Universitas Wiraraja juga mendapatkan perhatian yang serius bagi kalangan mahasiswa akuntansi. Terdapat beberapa mahasiswa akuntansi (Putri dan Sutrisno) yang berpendapat bahwa mata kuliah akuntansi forensik perlu dimasukkan kedalam kurikulum jurusan akuntansi. Karena akuntansi forensik dianggap sebagai suatu bidang profesi yang mempunyai peluang karir yang dapat ditempuh mahasiswa yang ingin fokus pada bidang akuntansi forensik seperti melanjutkan ke jenjang S2 atau untuk mengikuti sertifikasi akuntansi forensik. Dengan memasukkan akuntansi forensik kedalam kurikulum jurusan akuntansi bisa menjadi salah satu langkah awal untuk pemilihan karir mahasiswa akuntansi.

Namun disisi lain, beberapa mahasiswa akuntansi (Yesi dan Dendi) juga berpendapat bahwa akuntansi forensik masih belum perlu dimasukkan kedalam kurikulum jurusan akuntansi. Ungkapan dari mahasiswa tersebut lebih menekankan pada berbagai faktor yang harus disiapkan sebelum mata kuliah akuntansi forensik dimasukkan kedalam kurikulum jurusan akuntansi. Misalnya seperti kesiapan dosen yang ahli dibidang akuntansi forensik, kesiapan mahasiswa yang akan menerima pembelajaran tentang akuntansi forensik juga harus dipertimbangkan. Dan 
prospek akuntansi forensik kedepan juga harus dipertimbangkan. Untuk itu mata kuliah akuntansi forensik masih belum perlu dimasukkan kedalam kurikulum jurusan akuntansi. Karena butuh beberapa pertimbangan yang harus dilakukan sebelum merubah suatu kurikulum.

Berbeda halnya dengan ungkapan salah satu pegawai inspektorat pemerintah kabupaten sumenep yaitu Bapak Moh. Fatah Firdaus yang merupakan salah satu lulusan S2 akuntansi forensik lebih lugas mengungkapkan akan kebutuhan suatu instansi terhadap seorang akuntan forensik yang menganggap bahwa mendeteksi dan menyelesaikan suatu kecurangan pada suatu entitas publik maupun swasta tidak cukup dengan audit umum saja. Perlu pengetahuan tentang akuntansi forensik secara mendalam. Maka dari itu sebagai langkah awal mahasiswa perlu dibekali dengan ilmu yang dapat mencegah dan mendeteksi suatu tindak kecurangan seperti halnya akuntansi forensik.

Senada dengan pendapat Bapak Moh. Fatah Firdaus, Kepala Bagian Operasional PT. BPRS Ibu Endang juga berpendapat bahwa akuntansi forensik perlu untuk dijadikan sebagai mata kuliah di Program Studi Akuntansi Fakultas Ekonomi Dan Bisnis. Hal ini dapat dijadikan dasar pemahaman bagi mahasiswa sebagai antisipasi terjadinya tindak kecurangan karena mengingat fraud tidak hanya terjadi pada dunia pemerintahan akan tetapi pada sektor swasta. Dengan memasukkan mata kuliah akuntansi forensik kedalam kurikulum jurusan akuntansi juga dapat menjadi acuan bagi mahasiswa akuntansi untuk memilih fokus dalam bidang akuntansi forensik.

Jurusan akuntansi mempunyai tujuan untuk membentuk lulusan yang professional, berkarakter dan berkompetensi dalam disiplin ilmu akuntansi. Kurikulum pada jurusan akuntansi harus dapat menyesuaikan dengan lingkungan akademis dan profesi yang sedang dibutuhkan pada saat perkembangan bisnis semakin meningkat dan tidak menutup kemungkinan tindak kecurangan juga akan semakin meningkat. Maka dari itu perlu bagi program studi akuntansi mempertimbangkan tentang masalah kurikulum dan kebutuhan stakeholder lulusan akuntansi yang saat ini dibutuhkan

\section{CONCLUSIONS}

Berdasarkan hasil penelitian dan pembahasan yang sudah dipaparkan maka dapat ditarik suatu kesimpulan bahwa dari tiga dosen yang telah diwawancarai oleh peneliti terdapat satu dosen yang berpersepsi bahwa akuntansi forensik perlu untuk dimasukkan kedalam kurikulum Program Studi Akuntansi Fakultas Ekonomi Dan Bisnis. Dan terdapat dua dosen yang berpersepsi bahwa akuntansi forensik tidak perlu dimasukkan kedalam kurikulum Program Studi Akuntansi Fakultas Ekonomi Dan Bisnis Universitas Wiraraja.

Dari empat mahasiswa akuntansi yang telah diwawancarai oleh peneliti ada dua mahasiswa (putri dan akhmad sutrisno) yang berpendapat bahwa akuntansi forensik perlu dimasukkan kedalam kurikulum Program Studi Akuntansi Fakultas Ekonomi Dan Bisnis. Sedangkan dua mahasiswa lainnya (Dendi dan Yesi) berpendapat bahwa akuntansi forensik masih belum perlu dimasukkan kedalam kurikulum.

Stakeholder berpendapat bahwa akuntansi forensik perlu dimasukkan kedalam kurikulum program studi akuntansi. Paling tidak mahasiswa mempunyai pengetahuan dasar tentang akuntansi forensik sebagai bekal bagi mahasiswa yang nantinya akan 
melanjutkan pada jenjang selanjutnya misalnya untuk mengikuti sertifikasi akuntansi forensik atau untuk meneruskan pada penjurusan yang berfokus akuntansi forensik.

Dari penelitian yang sudah dilakukan pada UMKM AL-IHSAN ini, peneliti bisa memberikan saran diantaranya bagi program studi akuntansi fakultas ekonomi dan bisnis perlu mempertimbangkan akuntansi forensik dimasukkan kedalam kurikulum akuntansi walaupun hanya sebagai mata kuliah pilihan. Karena pada kenyataannya terdapat beberapa stakeholder yang menyatakan bahwa akuntansi forensik perlu dimasukkan kedalam kurikulum jurusan akuntansi. Sedangkan untuk peneliti selanjutnya sebaiknya lebih meningkatkan penelitian lebih luas tidak hanya berfokus pada satu lembaga pendidikan. untuk lebih meningkatkan persepsi tentang pentingnya mata kuliah akuntansi forensik dalam kurikulum program studi akuntansi.

\section{REFERENCES}

Chyntia Wibowo dan Gugus Irianto (2014). Persepsi Mahasiswa Akuntansi Tentang Penyelengaraan Pendidikan Anti Korupsi Di Perguruan Tinggi. Fakultas Ekonomi dan Bisnis Jurusan Akuntansi Universitas Brawijaya Malang.

Davis, C., Farrel, R. \& Ogilby, S. 2010. Characteristics and Skills of the Forensic Accountant. Hal 1-34 America: AICPA

Detik News: Https://news.detik.com/berita/d3621894/icw-dalam-6-bulan--226-kasuskorupsi-rugikan-negara-rp-183-t

Eme Joel Efiong (2014). Forensic Accounting Education: An Exploration of Level of Awareness in Developing Economies Nigeria as a Case Study. International
Journal of Bussines and Management, 5, $1-9$.

Gbegi, D.O \& Adebisi, J. F. Ph. D (2014). Forensic Accounting Skills And Techniques In Fraud Investigation In The Nigerian Public Sector. Mediterrabeab Journal of Social Sciences, 5, 1-10.

Hasan, M. Iqbal. (2008). Pokok - Pokok Materi Statistik 1 (Statistic Deskriptif) Edisi Kedua. Jakarta: Bumi Aksara

Jumansyah, Nunik Lestari Dewi, Tan Kwang (2012). Akuntansi Forensik Dan Prospeknya Terhadap Penyelesaian Masalah-Masalah Hukum di Indonesia. Fakultas Ekonomi Universitas Al-azhar Indonesia Bandung.

Kamus Besar Bahasa Indonesia. 2007. Departemen Pendidikan dan Kebudayaan, Balai Pustaka

Mar'at. 1992. Sikap Manusia: Perubahan Serta Pengukurannya, Jakarta: ...

Miftah Toha. 2003. Perilaku Organisasi Konsep Dasar dan Aplikasinya. Jakarta:Grafindo Persada.

Muchlas, Makmuri. 2008. Perilaku Organisasi. Yogyakarta: Gadjah Mada University Press.

Setiawan, A.R., G. Irianto, \& M. Achsin (2014). System-driven (Un) Tafsiran Aparatur Terhadap "Sisi Gelap" Pengelolaan Keuangan Daerah". Jurnal Akuntansi Multiparadigma Vol. 4 No. 1, hlm 85-100.

Rahman, A (1999). Auditing Forensik dan Kontribusi Akuntansi Dalam Pemberantasan Korupsi. Universitas Islam Indonesia Bandung.

Rakhmat, Jalaludin 2007. Persepsi Dalam Proses Belajar Mengajar. Jakarta: Rajawali Pers. Jogiyanto.

Sri Rahayu Husen. (2017). Persepsi Akademisi, Praktisi, Dan Mahasiswa Akuntansi Terhadap Keahlian Akuntan 
Forensik Di Makassar. Fakultas Ekonomi Ekonomi Pembangunan Universitas Tompotika Luwuk.

Sugiyono, 2012. Metode Prenelitian Kuantitatif, Kualitatif dan $R \& D$. Bandung: Alfabeta

Sugiyono. 2015. Metode Penelitian Kuantitatif Kualitatif Dan $R \& D$. Bandung: Alfabeta.

Tiaz, F.W. (2012). Perlukah Mahasiswa Strata Satu Akuntansi di Indonesia Memiliki Persepsi Audit Forensik?. Fakultas Ekonomi dan Bisnis Jurusan Akuntansi Universitas Negeri Surabaya.

Tuanakotta, T.M. 2013. Akuntansi Forensik \& Audit Investigatif. Edisi Kedua. Jakarta: Salemba Empat

Tuanakotta, Theodorus M.2010. Akuntansi Forensik \& Audit Investigatif. Jakarta: Salemba Empat
Walgito, Bimo. (2010). Pengantar Psikologi Umum. Yogyakarta: Penerbit Andi.

Web resmi Universitas Wiraraja https://wiraraja.ac.id/

Web resmi Fakultas Ekonomi dan Bisnis Universitas wiraraja https://feb.wiraraja.ac.id/

Zimbelman, Mark F., C. Conan., Steve, W., \& O, Chad. (2014). Akuntansi Forensik, Edisi Keempat. Jakarta: Salemba Empat. 